\section{FUTURES OF}

GAMING: HOW

CASINOS AND

GAMBLING MIGHT

EVOLVE IN THE

NEAR FUTURE

\section{DAVID G. SCHWARTZ}

David G. Schwartz is the associate vice provost for faculty affairs at the University of Nevada, Las Vegas, in Las Vegas, Nevada.

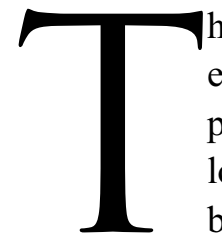
ently innate, as the history of gambling proves. Gambling has been around a long time and has seen many changes, but many of those in the gaming industry believe the generational shifts the business now faces are unprecedented, with potentially dire consequences for the industry. Many fear that millennials will not gamble unless casinos make extraordinary efforts to accommodate them. While visitors to Las Vegas appear to be spending significantly less time gambling, both commercial and tribal gaming revenues are at record highs. In addition, sports betting, particularly on mobile devices, it set to grow significantly while the esports industry is growing at a dramatic pace.

Shifts in the way that people choose to gamble are not new. Gambling has always evolved with technology and the paths open to gaming in the future are consistent with the historical evolution of gambling. Even the relatively brief history of the modern casino shows that this is the case.

For example, baccarat, which is the highest revenueproducing table game in some jurisdictions, was not widely played even 40 years ago while faro, which dominated gambling halls in the nineteenth century, is a relic. Slot machines have an even shorter lifespan, and many of the games that are popular today have features that would have been unthinkable 20 years ago.

This is not to say that casinos have nothing to worry about. The changes that the casino gaming industry are beginning to see may bring much larger disruptions to the business than anyone currently realizes. Again, history provides something of a guide. The casino resort, the basic building block of the modern casino gaming industry, only became a major locus of American gambling in the last 75 years. The casino resort's rapid rise was predicated on a series of cultural, political, and legal factors that coalesced in the second half of the twentieth century to produce a favorable climate for the birth and growth of the institution, and as those factors shift, it is only logical to expect a divergence between gambling and the casino resort.

\section{GAMBLING IS OLD AND SO IS THE BUSINESS OF GAMBLING}

Physical evidence of gambling has been found in the oldest archaeological digs in Europe, Mediterranean, and Near East, suggesting that the activity is, at the least, as old as organized societies. ${ }^{1}$ The earliest games for which records exist used extremely simple technology. A game like "odds and evens" had players bet on whether a selected group of markers would number odd or even (a surviving descendant is the game of fantan). It is clear from even a cursory review of gambling history that the materials and tools used to gamble have evolved with technology. The first items used as dice were astralagi, or the ankle bones of goats and sheep. With four asymmetrical sides, rolling them produced a semi-random result. While not precise, this was good enough to satisfy the gamblers of the time, who had little understanding of the concepts of randomness or probability.

These early games had in common that they were social: players bet against each other, with no central 
bank or house. Play was at the discretion of each player, with stakes and any deviation from accepted rules mutually agreed upon. As such, there was not much of a business around gambling. However, some gambling professionals emerged. These professionals consistently won by cheating - the only way to secure an edge in social games. Professional gambling had a sense of dishonor attached to it. This stigma goes back to at least the time of the compilation of the Talmud, a compendium of Jewish law from the fourth to sixth centuries. The assemblers of the law maintained that habitual dice players could not be witnesses or magistrates because they "did not occupy themselves with the welfare of the world."2 The intimation, that professional gamblers were inherently untrustworthy, was not at all undeserved, owing to the nature of the games themselves, and the fact that the only way to be guaranteed a profit was to cheat.

There were, however, businesses that profited from gambling. While social games of dice could take place anywhere, players often congregated in taverns, where they could shoot dice as well as enjoy food, drink, and other diversions. ${ }^{3}$ In the West, gambling in taverns can be traced back to the early Roman Empire, where play in the backrooms of inns, food stalls, and taverns was tolerated. ${ }^{4}$ Similarly, gambling houses - which provided space and equipment for gambling in return for a share of the proceedswere found in ancient China and India. ${ }^{5}$

These businesses, even when completely dedicated to gambling rather than offering a space for it in return for the purchase of food, drink, or entertainment, did not permit players to bet directly against them. This would be tantamount to a gym or athletic club fielding paid teams against paying members, rather than providing basketball courts that members use to play against each other. And as long as gambling games remained social in nature, there was no reason to change the basic structure of gambling businesses. One might make money tolerating or even facilitating play, but there was no sustainable method for profiting from the games themselvesbarring, of course, cheating by individual players.

The discovery of mercantile gambling changed the nature of gambling and made possible the creation of gambling businesses that allowed customers to wager directly against them. Mercantile games, which could be played using dice, cards, wheels, or even lottery tickets, had in common one basic idea: a discrepancy between the true odds of the game and the payout offered to customers. The game of double-zero roulette is illustrative. A player betting on red is paid even money when winning, which would lead to a dead-even game but for the presence of the zero and double zero, which means that, out of the 38 possible outcomes of a spin, only 18 result in a win. The result is a game with a "house edge" or "percentage" of 5.26 percent. The phenomenon is even clearer when looking at single-number bets, where the two-unit gap between the "true" odds (37 to 1 ) and the payoff (35 to 1) is the house edge (it is the same as the percentage for the even-money bets). ${ }^{6}$

The emergence of mercantile gambling made possible the rise of gambling businesses that directly profited from customers that bet against them. These businesses could be based on different games, but had one thing in common: in return for government support, they gave a portion of their revenues to the state. Lotteries were the first serious gambling business to develop in Europe, with the first one of which there is a surviving record appearing in L'Ecluse, Flanders, in 1444. This initial draw was organized specifically to raise money to repair the city's walls. ${ }^{7}$ Private merchants often took the lead in debuting this new form of gambling; in Venice, for example, secondhand clothes dealer Geronimo Bambarara offered a lottery game in 1522. After other businesses turned the Rialto into a virtual gambling zone, the Venetian government stepped in and began offering its own sanctioned games. ${ }^{8}$

\footnotetext{
${ }^{2}$ The Babylonian Talmud: Tract Sanhedrin. Section Jurisprudence (Damages) 72 (Michael L. Rodkinson, trans., Boston: Talmud Society, 1918).

${ }^{3}$ David G. Schwartz, Roll the Bones: The History of Gambling 36-7 (New York: Gotham Books, 2006).

${ }^{4} I d$. at $28-9$.

${ }^{5} I d$. at 12,16 .
}

${ }^{6}$ Robert Hannum, Casino Mathematics, UNLV Center for GAMING ReSEARCh (last modified June 5, 2012), accessed at: https://gaming.unlv.edu/casinomath.html\#he.

${ }^{7}$ SCHWARTZ, supra note 3 , at 84 .

${ }^{8} I d$. at 85 
Despite a dip in popularity in the nineteenth and early twentieth centuries, lotteries have remained popular sources of government revenue for centuries. Lotteries were often organized by private operators who contracted with the government thus creating a partnership between the business and the government. A similar model of partnership between business and government was evident in the thriving gambling culture of Venice, which was built upon gambling resorts, in which the government would profit from mercantile games by taking a cut of the proceeds.

\section{THE RISE OF THE GAMING RESORT}

The Western tradition places the origin of the legal, state-sanctioned casino in early seventeenth-century Venice. While gambling was long popular in Venice, particularly during Carnival season, it was not until 1638 that the Grand Council legalized it. A single impoverished noble family, the Barnabotti, were given the franchise to offer state-sanctioned gambling at the San Moise Palace. The Barnabotti had been living on the dole, as they were aristocratic and therefore forbidden from seeking the work of lesser classes, even as their own wealth dissipated. The Grand Council's decision effectively passed the burden of supporting the Barnabotti from the general coffers of the state to the wallets of the gambling public.

When viewed in context, the Ridotto owed its birth to a confluence of circumstances. The poverty of the Barnabotti gave this politically powerful family an incentive to explore new ways to earn a living. The onus of supporting the Barnabotti placed a fiscal obligation on the Venetian government. The declining fortunes of Venice made money harder to raise, inspiring a certain entrepreneurial spirit within the Grand Council. Finally, the pervasive social acceptance of gambling, particularly during the six-month carnival season, undercut the legal fiction that it was a suppressed activity. In addition, the presence of a large number of travelers and tourists, many of whom were lured by the thrills of the carnival, presented the possibility that Venice could benefit by si- phoning money from this ready pool of disposable income. ${ }^{9}$

For generations, the Ridotto worked well enough for all parties involved, and became a must-see stop for visitors to the City of Canals. The fact that such games could be played legally was such a lure that the Ridotto was enlarged. In fact, the lures of the gambling palace worked too well; by the 1770s, some Venetians were outraged that the fortunes of venerable noble families were being lost to the gaming tables. For that reason, the republic's Grand Council passed a resolution closing the Ridotto in $1774 .^{10}$

However, the idea that a gambling resort could be used to solve a jurisdiction's financial problems was too good to remain on the shelf. Throughout Europe, a series of gambling spas opened their doors. Located mostly in small, resource-poor jurisdictions without many other avenues of economic development, these resorts usually catered to residents of larger states that had prohibited gambling.

Spa, a resort town that today is in Belgium, was one of the earliest of the small jurisdictions to embrace gambling. Its first gambling concession opened in 1765. The town enjoyed boom years until 1789, when the French Revolution and the wars that followed put a damper on lavish gambling. ${ }^{11}$ In the early nineteenth century, Spa declined as other, more easily accessible, and frankly more alluring resorts appeared. Lack of a modern transportation infrastructure handicapped Spa, but shifting fashions doomed it. As gaming historian Russell Barnhart concludes:

In particular such German towns as Weisbaden, Ems, Kissingen, Bad Homburg, and Baden Baden had captivated society's fancy. The ambience of these new German watering places, the greater elegance of their landscapes, promenades, casinos, and more accessible springs, as well as their more charming hospitality, seduced away from Spa its former clientele and appealed to the new generation as mirroring their own 
youth, vigor, and romanticism. However attractive and refurbished was Spa in the 19th century, it seemed to represent too much the Age of the Rococo, and apparently no one wished to turn back the clock. ${ }^{12}$

Those "German" resorts (Germany as a nation-state did not exist until the declaration of the German Empire in 1871) had more than fashion on their side. They took advantage of the 1837 prohibition of gambling in France, which not only denied Frenchmen and women legal places to gamble, but also freed up the human capital of hundreds of dealers, supervisors, and other gambling experts, who gave the resorts Barnhart cites a boost in both expertise and credibility with the French gambling public. ${ }^{13}$

The rise of the Blanc brothers' operation in Bad Homburg is instructive. Following a conviction for bribery and corruption in Bordeaux, they were eager to put some distance between themselves and their native France. After opening a small casino in Luxembourg in 1838, the brothers got to know Lewis William, the landgrave of Hesse-Homburg, who was stationed as military governor there. They learned that, since 1824, three gambling concessions had been granted in Homburg, but all had failed, likely due to lack of capitalization which was not a problem for the Blancs who, despite their conviction, managed to keep most of their ill-gotten Bordeaux gains. After William died, the Blancs successfully negotiated with his brother (and new landgrave) Philip August to commence gambling operations in Bad Homburg. ${ }^{14}$

After a temporary location proved successful on its 1841 launch, the Blancs threw themselves into building an elegant casino known as the Kursaal, which opened in $1843 .{ }^{15}$ Before their arrival, Homburg had struggled to attract dozens of guests in a year (the 1834 total, for example, was 155). In the Kursaal's first year of operation, Homburg attracted nearly 2,700 visitors, a number than would rise al- most ten-fold over the ensuing three decades. ${ }^{16}$ The pleasant scenery, trusted dealers, and managerial savvy of the Blancs combined to make Bad Homburg a popular spot with gambling tourists, much to the delight of the landgrave. This same scene was played out across the Rheinland, as small, resource-poor Germanophone jurisdictions profited from their political independence and the wealth of both gamblers and administrative expertise that had fled France.

The good times for spa resorts would come to an end in 1872, when a newly unified Germany that now included those small, liberally inclined jurisdictions, outlawed gambling. Luckily, another small, resource-poor jurisdiction that had resisted incorporation into France, Monaco, was ready to exploit Prussian prohibition. As at Bad Homburg, Monaco's rulers had a few miscues with concessionaires before partnering with Francois Blanc in 1863 (Louis Blanc had passed away in 1855). Under Blanc's leadership, Monaco became home to Monte Carlo, the peerless gaming resort of Europe. ${ }^{17}$ Contemporary travel writer W.J.A. Stamer eulogized Blanc (who died in 1877) in an 1894 survey of the gambling resort by noting all he had done to bring Monte Carlo into prominence:

By the unsparing use of printers' ink, Monaco the little known had become Monaco the renowned, or the notorious. By the opening of the railway the road thither had been made easy, if not precisely safe, and last, not least, the suppression of the German gaming tables had, by the enforced retirement of their respective tenanciers, left M. Blanc without a rival in the field. Rich beyond his most sanguine expectations-archi-millionaire - an authority on all matters connected with finance; courted, admired, bepraised, his elder daughter married to a prince, M. Blanc exemplified the truth of the adage "Nothing succeeds like success."

While Blanc's personal drive and genius played a large part in the success of Monte Carlo as a gaming

\footnotetext{
${ }^{12} I d$. at $92-3$.

${ }^{13} \mathrm{Id}$. at 136 .

${ }^{14} I d$. at $136-8$.

${ }^{15} \mathrm{Id}$. at 138

${ }^{16} I d$. at 141
}

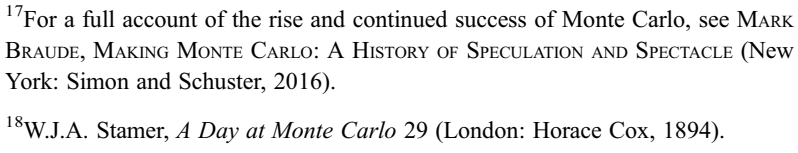

${ }^{17}$ For a full account of the rise and continued success of Monte Carlo, see MARK Braude, Making Monte Carlo: A History of Speculation and Spectacle (New York: Simon and Schuster, 2016).

${ }^{18}$ W.J.A. Stamer, A Day at Monte Carlo 29 (London: Horace Cox, 1894). 
resort, a confluence of factors, ranging from the social norms that governed gambling among wealthy (and not so wealthy) Europeans to the political considerations that undergird prohibition, combined to make the conditions right for Monte Carlo to flourish.

By the same token, shifting political and social realities led to the decline of Monaco as a gaming resort. The French government's 1907 legalization of baccarat paved the way for the rise of numerous small clubs and casinos throughout the country. ${ }^{19}$ Throughout the continent and in the British Isles, Europeans found ways to gamble that were more adept to the rhythms of the new century, as the dress codes and guest lists of Blanc's Monte Carlo became more outdated. Monte Carlo adapted to new tastes, bringing in slot machines and even craps, but never regained its place as the world's preeminent gambling destination. $^{20}$ That title would pass to a resort in another resource-poor jurisdiction that also took advantage of surrounding prohibition to build an allure that was difficult for gamblers to resist.

\section{THE DOMINANCE OF THE AMERICAN GAMING RESORT}

Nevada was born in battle (the Civil War, to be precise) and was initially dominated by mining, banking, and railroad interests. Gambling, legalized in 1869 and criminalized in 1909, was more a pastime than an industry in its first incarnation. Usually taking place in bars and saloons, Nevada gaming (as the practice was statutorily known from its inception) was decidedly small scale. For that reason, its prohibition was not viewed as a cataclysm. The Las Vegas Age, for example, coolly reported that Governor Denver Dickinson had signed an "anti-gambling" bill, which ended the issuance of licenses and made playing any game for money a misdemeanor. ${ }^{21}$ This ban on gambling was far from absolute, and was rolled back almost immediately. By 1919, both cities and counties were licensing card rooms where social games like poker were played, and slot machines

\footnotetext{
${ }^{19}$ Schwartz (CAsino Edition), supra note 1, at 80-81.

${ }^{20} I d$. at 88 .

${ }^{21}$ Nevada's Chief Executive Signs 4 Important Bills, Las Vegas Age, Apr. 3, 1909, at 2 .

${ }^{22}$ Eric N. Moody, Nevada's Legalization of Casino Gambling in 1931: Purely a Business Proposition, 37 Nev. Hist. Soc'y Q. 79, 80 (Summer 1994).
}

played for low stakes and pari-mutuel horse race betting were also permitted. ${ }^{22}$

While this arrangement seemed to satisfy the general public and local governments, a coalition of gamblers, businessmen, and their political supporters continued, throughout the $1920 \mathrm{~s}$, to advocate for a broader legalization of gambling that would return Nevada to its pre-1909 “wide-open” status. In February 1931, Nevada adopted a "wide-open" gambling bill after an eight-month campaign by the gamblers, developers, and other business interests who believed they would profit from the increased opportunities offered by less restrictive gaming legislation. ${ }^{23}$

Initially, Nevada gaming did not change much following legalization. Bank games that had been in backrooms became publicly visible, but for the most part, gambling did not become a major business. Reno continued to be the state's major city, and its gambling halls were the center of Nevada's gaming industry, such as it was. Indeed, divorce, rather than gambling was the major attraction for many Reno visitors in early 1931. The state's "quickie" divorce law allowed no-fault uncoupling after one party established Nevada residence, for six weeks. A variety of Reno attractions, from a golf course to a private school, blossomed because of the divorce trade, while gambling, which in 1931 had a smaller capital investment than it did in 1906, was still seen as an iffy proposition. ${ }^{24}$

Gambling halls in Las Vegas were similarly small, although they did have a built-in visitor base that Reno lacked: workers on Hoover Dam, who had sizable paychecks but few diversions in Boulder City. Small-stakes roulette, slot machines, bingo, and keno were the most popular games, as these gambling halls, like locals' casinos today, catered primarily to small-stakes, high-repeat visitors. ${ }^{25}$ An October 1931 New York Times article reported that both Reno and Las Vegas had been "flops" as gambling destinations, though it held out the possibility that the pendulum might, one day, swing the other way. ${ }^{26}$

\footnotetext{
${ }^{23} I d$. at 84 .

${ }^{24}$ J.F. McDonald, Reno Gains Foothold on Divorce Industry, WASH. Post, Apr. 27, 1931 , at 2 .

${ }^{25}$ Frank Wright, Nevada Yesterdays: Short Looks at Las Vegas History 48 (Las Vegas: Stephens Press, 2005).

${ }^{26}$ Gambling Loses Lure at Western Resorts, N.Y. TIMEs, Oct. 4, 1931, at 57
} 
The pendulum did, indeed, begin to swing in favor of Nevada gaming, but not immediately. The Mexican government's 1935 suppression of gambling, which closed a casino at Agua Caliente that appealed to Southern Californians, led the Las Vegas Chamber of Commerce to publish an open appeal to "gamblers and horsemen" to set up shop in Las Vegas, "the most liberal town in the West."27 That influx of capital and expertise did not happen, but a crackdown on illegal gambling in Los Angeles that began in 1939 forced an exodus of Los Angeles-based gambling entrepreneurs, including the (recently) former LAPD vice captain Guy McAfee. McAfee would open the 91 Club on Los Angeles Highway/Route 91 and the Golden Nugget, and Benjamin Siegel and Moe Sedway invested in the El Cortez before taking over and opening fellow Angeleno Billy Wilkerson's stalled Flamingo. ${ }^{28}$

The small-stakes gambling halls of downtown Reno and Las Vegas were well-suited to the 1930s, when the United States was still in the throes of the Great Depression and the viability of the gaming industry had yet to be demonstrated. With little certainty that Nevada's tolerance of gambling would continue or that gambling would be more than a curiosity for tourists, investment in gaming operations remained relatively small. The 1931 legislation had cleared the way for Nevadans to legally own businesses that offered a full range of games, but there was no demonstrated demand for anything more than a handful of slot machines and table games (along with keno parlors) found in the clubs mixed in with the downtown commercial districts of Nevada's major cities. But changing social, economic, and political conditions would, within 15 years of the Los Angeles crackdown on vice, facilitate the beginnings of a new kind of gambling in a new kind of structure: the casino resort.

The Los Angeles influx initially brought capital and gaming know-how to Fremont Street, but another Californian set in motion a series of developments that would shift south, to the Los Angeles Highway, which would ultimately be rechristened the Las Vegas Strip. Thomas Hull, who already owned a pair of
El Rancho motor court motels in California, was lured to Las Vegas in search of a "first class hotel" that would help the city capitalize on both its permissiveness and its proximity to the recently-completed Hoover Dam. Rather than build his hotel near the train station in Downtown Las Vegas though, Hull decided to construct a sprawling, bungalow-style resort with a casino and dinner theater just south of the city limits, at San Francisco Street and Highway 91. ${ }^{29}$

Hull's El Rancho Vegas was an adaptation to changing public tastes. As a Californian, he knew the growing dominance of the automobile. He believed visitors would be more likely to drive to Las Vegas than ride the train and a sprawling resort on the road from Los Angeles would have the first shot at Angelenos. And just as importantly, the setting of gambling within the El Rancho Vegas would distinguish it from that inside the downtown gambling halls. On Fremont Street, gambling and drinking were the only real attraction. For those who had grown up with gambling as a fact of Nevada life, this wasn't a problem. But there was little allure for visitors who, while they might enjoy a game of chance, were not convinced this wasn't a seedy activity. Hull's El Rancho Vegas, by contrast, offered gambling as one of several rustic but urbane diversions. During warmer months, visitors could lounge by the pool all day before heading inside for a dinner show. In that context, dropping a few dollars at the tables seemed more acceptable.

Despite a revolving door of owners over its first several years, the El Rancho Vegas was profitable enough to inspire others to build on Highway 91. The Last Frontier (1942) and Flamingo (1946) demonstrated that Hull's basic concept, a self-contained casino resort, could be a success. ${ }^{30}$ The Thunderbird (1948), Sahara (1950), Desert Inn (1950), and Sands (1952) elaborated on the resort paradigm, so that by 1955, when five new casino hotels opened, there was little new to be added to the model. By that time, thanks to the success of the casino resort, Las Vegas had not only displaced Reno as the nation's premiere "sin city," but had become a national vacation destination.

\footnotetext{
${ }^{27}$ Las Vegas Makes Bid, L.A. Times, July 23, 1935, at A1.

${ }^{28}$ WRIGHT, supra note 25 , at 51 .

${ }^{29}$ David G. Schwartz, The Columbus of Highway 91, VEGAS SEvEn, Nov. 8, 2012.
}

\footnotetext{
${ }^{30}$ For a more complete discussion of the rise of the casino resort, see DAVID G. Schwartz, Suburban Xanadu: The Casino Resort on the Las Vegas Strip and BEYOND (New York: Routledge, 2003).
} 
Casino resorts worked on the Strip for a variety of reasons, both internal and external. Within the operation itself, a large, self-contained facility made for a more profitable casino because it encouraged gamblers to play longer, thus generating more decisions, which in turn limited volatility and made it more likely for lucky winners to lose back their winnings. Food, beverage, and even entertainment could be run at a loss, thus offering higher quality at a lower price than would be possible at a non-gaming resort, providing an inducement for casual vacationers to stay - and perhaps bet a few dollars. Casinos in integrated resorts far outperformed their standalone counterparts. Even on Fremont Street, the old model — a bar with a few gambling options - was eventually pushed out by casino hotels that, while lacking the full range of Strip amenities, were far more sophisticated than anything that had been built in the 1930s. Attempts on the Strip to run a casino-less hotel (Tally-Ho) and hotel-less casino (Circus Circus) failed; Tally-Ho, with an added casino and quick change in theme, became the Aladdin, while Circus Circus only became profitable after the addition of a hotel (and a change in management).

The appeal casino resorts held for customers was boosted by two primary factors. First, as casino resorts grew in Las Vegas, the United States was in the midst of an era of affluence. As more Americans had the time and leisure to travel, tourism to destinations like Las Vegas from the East Coast and Midwest, which would have been restricted to only the welloff a generation earlier, became common. Closer to home, Los Angeles was booming, and the rise of Southern California helped benefit Las Vegas, which established itself as a playground not just for Hollywood royalty, but for Angelenos of all stripes.

Second, while Nevada was profiting from legal gambling, the rest of the nation was turning against the practice. From 1950 to 1951, the Senate's Special Committee to Investigate Organized Crime in Interstate Commerce (popularly known as the Kefauver Committee, after its publicity-seeking chair, Estes Kefauver) raised public awareness about the alleged links between illegal and legal gambling and organized crime. Whereas Americans had earlier considered illegal gambling to be a purely local issue, following the committee's televised hearings they were increasingly aware that criminal groups with national range profited from illegal (and, allegedly, legal) gambling. ${ }^{31}$ Following the publicity generated by the Kefauver Committee, many previously wideopen jurisdictions around the country which had tolerated technically illegal gambling operations, from urban slot routes to posh clandestine casinos, tightened their enforcement of existing laws and voted against permitting new forms of gambling. Even a potential Caribbean rival followed suit as, following the Cuban Revolution, the Fidel Castro-led communist government outlawed the nation's casinos, which had catered primarily to Americans.

Las Vegas was built on a model, the casino resort, which was in turn predicated on creating a "captive audience" of gamblers. A large resort hotel with numerous amenities tied to a gambling casino made perfect sense in a tourist destination hundreds of miles from the nearest major city. The Mojave functioned as a sort of quarantine zone, containing the morally dubious gambling behind a protective desert screen. Thematically, the resorts themselves tended to distance their offerings from contemporary America. A Western theme predominated into the 1960s that put Las Vegas gambling into the context of America's frontier past (which was beloved thanks to the popularity of television and film Westerns) rather than urban corruption, the milieu from which most operators actually emerged. Even when resorts went beyond the American West for their themes, they settled on exotic locales, like the Caribbean, Middle East, and Caesar's Rome. Casino resorts in Las Vegas worked, and Las Vegas prospered, by being fundamentally different from the rest of the United States. As an adaptation to the political realities of gambling prohibition, the economic fact of rising wealth, and the social proclivities of Americans to gamble, Las Vegas could not have emerged as a gambling destination anytime other than the middle of the twentieth century.

In other words, the rise of the Las Vegas casino resort as an institution was in response to a specific set of historical conditions, similar to those that produced Venice's Ridotto, the hot-spring-based gambling
${ }^{31}$ For a complete consideration of the Kefauver Committee's impact on the development of gaming in Las Vegas, see David G. Schwartz, Just a Passing Glance:
The Kefauver Committee in Las Vegas, 19(7) Gaming L. Rev. \& Econ 509-22 (2015) 
tourism of Spa, Bath, and numerous Rhine resorts, and Monte Carlo. Nevada, a resource-poor jurisdiction, had ample precedence for rolling the dice on gambling as an avenue of economic growth, and Las Vegas had many predecessors as a brilliant new destination.

While this is all well and good, it raises a question for those who have paid attention to history. It is now nearly 80 years since Thomas Hull opened the El Rancho Vegas. The Ridotto had a run of more than a century, but it closed. Changing fashions and realignments conjured the Rhine spas and Monte Carlo into existence and consigned them to relative obscurity. Is the casino resort, that innovation of mid-century Las Vegas, destined for a similar fate? For answers, the maturation and adaptation of the casino resort in Las Vegas from the 1960s through the present and its spread throughout the United States provide some clues.

Following a string of bankruptcies that attended the 1955 over-expansion of the market, casino operators refined their business model. Instead of appealing only to gamblers and vacationers (who filled hotels during the weekend but left them empty during the week), casinos started making concerted efforts to attract business travelers. This shift marked a milestone with the opening of the Las Vegas Convention Center in 1959, and may have reached its fruition with the 1999 opening of the Venetian, a resort that was designed as an all-suite convention hotel with a sizable casino attached.

Appealing to convention guests boosted hotels' midweek occupancy, allowing operators to build more rooms. While a typical resort of the 1950s might have two or three hundred rooms, many expanded in the 1960s, doubling or even tripling their size, while new resorts were considerably larger: Caesars Palace (1966) had 680 rooms at opening (and expanded three years later), while Kirk Kerkorian's International had 1,500 rooms at opening, eventually expanding to more than 3,000 .
One of the unintended consequences of the enlargement of the Las Vegas casino resort was a change in the nature of casino ownership in Nevada. Under the "old regime" that emerged in the 1940s and 1950s, most casinos were owned by small syndicates of investors. While there were safeguards in place to keep organized crime out, and flagrant examples of mob penetration were dealt with (Meyer Lansky's hidden interest in the Thunderbird and Frank Costello's connection to the Tropicana are two salient examples), the general attitude was that, as long as all of a casino's listed investors were real people who passed muster, regulators were not going to investigate the source of their funds too deeply. ${ }^{32}$

This was the era of what historian Hal Rothman called "shoebox capital." 33 In essence, money to build and expand casinos came from mobsters and others with less-than-legitimate income sources, who pulled money out of shoeboxes and sent it to Las Vegas in return for a cut of the future skim. Shoebox capital solved the problems of building small resorts in an industry with no exposure to mainstream finance, but it couldn't build something like Kirk Kerkorian's International, which cost $\$ 50$ million. To adjust to the new size of the industry, in 1967 and 1969 the Nevada legislature amended the state's gaming regulations to permit ownership by publicly traded corporations. ${ }^{34}$ Over the next 15 years, organized crime disappeared as a factor in casino ownership. As Rothman writes, "quickly and harshly, the old way of doing things in Las Vegas came to an end," as "organized crime suddenly became financially obsolete.",35

Mainstream finance enabled the next transition for the casino resort, as the recession of the late $1970 \mathrm{~s} /$ early 1980s resulted in another rethink and refocus for casino operators. The withering of high-end gambling dictated a turn to the mass market, which required investment in hotel expansions. ${ }^{36}$ This was just a prelude, however, to the "Mirage Revolution," which combined the theme elements of Caesars Palace with the mega-resort pioneered by Kirk Kerkorian
${ }^{32}$ David G. Schwartz, The Book That Tried to End Las Vegas, Vegas Seven, Sept. 4, 2012.

${ }^{33}$ Hal K. Rothman, Neon Metropolis: How Las Vegas Started the Twenty-First Century 15 (New York: Routledge, 2002).

${ }^{34}$ Nevada Gaming Law 21 (Las Vegas: Lionel Sawyer \& Collins, 1991).

\footnotetext{
${ }^{35}$ Rothman, supra note 33, at 22 .
}

${ }^{36}$ For an in-depth examination of the turn towards the mass market, see David G. Schwartz, The Burger King Revolution: How Las Vegas Bounced Back, 1983 1989, 14(4) Gaming L. Rev. \& Econ. 261-273 (2010). 
with the International and the original MGM Grand (1973). Casino resorts reinvented themselves as nongaming leisure and business travel destinations that just happened to have casinos attached. The Mirage Revolution was a structural response to the proliferation of casino gaming across the United States. As casino gaming lost its novelty, Las Vegas resorts needed something more than merely opportunities to play to distinguish themselves. Substantial investments in non-gaming and often non-revenue-producing amenities (like The Mirage's signature volcano and rainforest) made Las Vegas a destination unlike any of the new jurisdictions that came online.

The Las Vegas casino resort, as re-conceptualized during the 1990s, had four, sometimes five, elements: (1) a gambling casino, with slot machines physically dominating; (2) a large (3,000-room or more) hotel; (3) a range of food and beverage outlets, from snack bars to gourmet restaurants; (4) an entertainment presence, which could include multiple theaters and even arenas; and sometimes but not always (5) a major retail shopping experience. The casino resort was built around a perceived customer base of leisure, business, and casino customers who would be in Las Vegas for two to four days. ${ }^{37}$ Gambling customers would spend on average four hours a day at tables or seated at slot machines. As with the original generation of Strip resorts, a range of non-gaming attractions were intended to keep gamblers near the casino. Post-Mirage resorts, however, increasingly viewed each of the five elements as a revenue center in its own right. On the Strip, casinos had traditionally lost money from their dining division; as late as 1994, large (annual gaming revenues of more than $\$ 72$ million) Strip casino food departments together reported a deficit of nearly $\$ 22$ million for the year. But starting in 2005, food began generating revenue for Strip casinos. ${ }^{38}$

Yet even as non-gaming surpassed gaming as the leading revenue generator for Strip resorts, gaming remained the base of casinos' identity and operation.
And, outside of the Strip market, gaming remained the predominant source of revenues for casino resorts. The success of Nevada gaming - in particular the large, integrated, mainstream-financed resorts of the Las Vegas Strip, suggested to other states and tribal jurisdictions the solid development, employment, and jobs that casinos built on the Las Vegas model could bring. For this reason, the first state outside of Nevada to legalize casino gambling, New Jersey, mandated that all gambling take place within Striplike casino resorts.

New Jersey's intention to only permit gambling in casinos following the Strip resort model was made clear by its requirement that all gaming facilities have at least 500 rooms. The State Committee of Investigation, which delivered its report to the governor and legislature in April 1977, concluded that room requirements served "no valid law enforcement function," had no "discernable relationship to the betterment of casino operations themselves," and would tend to "limit the number of potential applicants for a gaming license." 39 Further, the committee noted that in Nevada, which had no statutory room requirement, "magnificent 1,000-room hotel/casino complexes have sprung up in addition to much smaller facilities. Dozens of casinos offering a wide range of sleeping accommodations and other amenities operate profitably. Yet this growth has been stimulated by the natural law of supply and demand, rather that [sic] by the artificial law of state-imposed minimumfacility requirements." 40

Lawmakers, however, insisted in the Casino Control Act (1977) - the enabling legislation that created the New Jersey casino industry - that gaming had been approved by voters "as a unique tool of urban development" that required the introduction of a limited number of casinos in "major hotel convention complexes." ${ }^{41}$ Thus, an approved hotel had to contain no fewer than 500 "sleeping units" of at least 325 square feet, each with a private bathroom. In addition, the main entrance to an approved hotel could not be
${ }^{37}$ For length-of-stay and time gaming data: Las Vegas Visitor ProflLe 1998, at 31 (Las Vegas: Las Vegas Convention and Visitors Authority, 1999).

${ }^{38}$ Nevada Casino Departmental Income, 1990-2017: Percentages and Totals for Selected Reporting Areas 3 (University of Nevada, Las Vegas: Center for Gaming Research, 2018).

\footnotetext{
${ }^{39}$ Report and Recommendations on Casino Gambling by the Committee of Investigation of the State of New Jersey 4-5-8 (Trenton: State Commission of Investigation, 1977)

${ }^{40}$ Report and Recommendations on Casino Gambling by the Committee of Investigation of the State of New Jersey 5-6-8 (Trenton: State Commission of Investigation, 1977).

${ }^{41}$ State of New Jersey, Casino Control Act, approved June 2, 1977, 1-4.
} 
"through a casino." 42 While many of the more stringent requirements of New Jersey's initial casino controls were later relaxed, the 500-room rule has remained (mostly) intact to the present day.

Ironically, even though the intent of the New Jersey law was to ensure that casinos were to be "offered and maintained as an integral element of such hospitality facilities, rather than as the industry unto themselves that they have become in other jurisdictions" (which could have only referred to Nevada), Strip casinos soon came to embrace the all-around hospitality model, while Atlantic City casinos, to this day, rely heavily on gaming income. ${ }^{43}$ Even more ironically, as its industry matured, Nevada followed New Jersey in mandating requirements for casino resorts. While a large number of existing operations were grandfathered in and the granting of restricted (fewer than 15 machines) licenses remained in place, in 1991 the legislature added NRS § 463.01865, which defined a "resort hotel" as "any building or group of buildings that is maintained as and held out to the public to be a hotel where sleeping accommodations are furnished to the transient public" with a mandated minimum 200- or 300-room count, depending on the size of the county, a bar with more than 30 permanent seats, a restaurant open around the clock with more than 60 seats, and a gaming area. $^{44}$

The formalization of the casino resort in Nevada law may have been the final proof of the model's success. The casinos that began to appear on state and tribal lands for the most part strived to follow the Strip model, even when constrained by requirements that gaming be conducted on riverboats that cruise. Today, however, there are no states with cruising requirements for casinos, and several states have allowed formerly water-borne gambling spaces to move onto dry land. Even when they are built in major cities, casinos inevitably follow the resort model.

${ }^{42}$ State of New Jersey, Casino Control Act, approved June 2, 1977, 2-27.

${ }^{43}$ State of New Jersey, Casino Control Act, approved June 2, 1977, 1-5. See Atlantic City Casino Statistics, UNLV CENTER FOR GAMING RESEARCH, https://gaming. unlv.edu/abstract/ac_main.html, for data on Atlantic City gaming/non-gaming (current as of 2011).

${ }^{44}$ Nev. Rev. Stat. § 463.01865 (2013), accessed at: https://www.leg.state.nv.us/ Division/Legal/LawLibrary/NRS/NRS-463.html\#NRS463Sec0177. The 100,000700,000 county population room count was the result of a 2012 amendment, accessed here: https:/www.leg.state.nv.us/Division/Legal/LawLibrary/Statutes/77th2013/ Stats201321.html\#Stats201321page3461.
Harrah's New Orleans casino, for example, was initially proposed as a stand-alone casino without restaurants, much less a hotel. Local hoteliers and restaurateurs wanted a casino that would benefit them; the casino resort model, which was consciously designed to prevent patrons from leaving the casino, had arguably restricted the impact of gaming on non-casino restaurants and hotels in Atlantic City. Following the bankruptcy of Harrah's first, temporary casino after only five months of operation, the Louisiana legislature made concessions to the company, and in 2006 the casino added a 450-room hotel. As of early 2018, Caesars Entertainment (Harrah's parent company) was seeking to build a second hotel, complete with restaurants and a nightclub. ${ }^{45}$

After nearly eight decades, the casino resort had become the default structure within which Americans (and, increasingly, those in Asian jurisdictions like Macau, Singapore, and potentially Japan) played casino games. But Venice's Ridotto had a 136-year run that ended. As the gaming industry faces behavioral and demographic shifts, could the casino resort's days be numbered?

\section{THE FALL OF THE GAMING RESORT?}

The economic, social, and legal factors that created and nurtured the casino resort are changing, partially because of the casino resort's success. Casino gambling is no longer restricted to Nevada, New Jersey, tribal lands, or riverboats, and is found in an increasing number of American cities. This has had a discernable impact on gaming in Las Vegas. While gaming revenues increased during the 1990s and reached new heights before the recession, gambling behaviors in Las Vegas have changed. ${ }^{46}$ In 1998, the average visitor to Las Vegas who gambled did so for four hours a day. By 2017, the average gambler spent only 1.9 hours a day gambling - a drop of more than 50 percent. ${ }^{47}$ While gambling budgets in real dollars

\footnotetext{
${ }^{45}$ Tyler Bridges, Harrah's New Orleans Pushing to Build 24-Story Hotel, Entertainment Venue in City, New Orleans Advocate (Feb. 1, 2018), accessed at: https://www.theadvocate.com/new_orleans/news/article_80cea0bc-07a3-11e8-88613b30a8ef52c3.html.

${ }^{46}$ For an overview of gaming revenue patterns in Nevada, see DAVID G. SCHWARTZ, Nevada Gaming Revenues 1984-2017: Calendar Year Results for Selected Reporting Areas (Las Vegas: Center for Gaming Research, University Libraries, University of Nevada Las Vegas, 2018).

${ }^{47}$ Las Vegas Visitor Profile 2017, at 31 (Las Vegas: Las Vegas Convention and Visitors Authority, 2018).
} 
have increased by 15 percent since 1998 , this is well below the rate of inflation, which would predict a rise of 50 percent. ${ }^{48}$ Visitors to Las Vegas are gambling and playing proportionally less - a potential canary in the coal mine for casinos everywhere, because if Las Vegas can't get gamblers excited, what hope does anywhere else have?

There are three potential explanations for this shift, and all are likely true to some extent. First, the availability of gaming elsewhere has robbed Las Vegas of its novelty, so visitors have less pent-up desire to gamble. Second, tighter slot machines and less favorable table rules (i.e., 6:5 blackjack) have reduced customer time on device, so that their gambling budget disappears more quickly. Third, there is the belief that younger potential customers - usually subsumed under the "millennial" label - are resistant to traditional casino games.

The first two factors, proliferation and worsening odds, are largely self-inflicted; the former is impossible to reverse, while the latter remains the subject of debate at gaming conferences. Yet angst over the third factor, younger customers not engaging with casino games as we know them, has sparked a cottage industry of developers, marketers, and influencers promising to lure millennials into casinos. The prevailing wisdom is that for casinos not to be considered a "grandma activity," they would have to invest in new designs, digital technologies, and social media engagement. ${ }^{49}$ Proponents of the millennial-rebrand strategy argue that, in the absence of some combination of the above initiatives, casinos will go the way of racetracks, who saw live attendance fall by nearly 50 percent over two decades. ${ }^{50}$

Racetracks are an interesting analogy for casinos, since while live attendance is at historic lows, betting on races has been bolstered by simulcast, off- track, and mobile wagering. ${ }^{51}$ Racetracks have also diversified their product offering by, in many cases, offering video lottery terminals or casino games (racinos). In other words, while the practice of betting on horses remains popular, the way that patrons do it has changed. While other patrons still want to gamble at the track, the games they want to play have changed. Racetracks have evolved to be able to appeal to both sets of gamblers while retaining their original, albeit declining, customer base.

Casinos have attempted to follow the racetrack "diversification" strategy by offering a different kind of electronic game, typically called a "skill game." Pioneered by companies like Gamblit and GameCo, these games let patrons blast zombies, snatch poker cards, or match smoothie ingredients. Frequently, they play against other patrons, rather than the casino itself. ${ }^{52}$ Skill games have had a mixed reception on casino floors: Caesars Entertainment's first experiment with skill games in Atlantic City ended after six months, as the games did not bring in sufficient revenues to cover vendor fees. In other words, the casino would be paying for the privilege of offering the game, rather than see it become a lucrative new revenue source. ${ }^{53}$ But before branding the skill game experiment a failure, it must be remembered that slot machines were, for decades, incidental to the main revenue source of casinos. It took several rounds of technological and game-play evolution, as well as an expansion of casino customer bases, for slot machines to dethrone table games as the leading casino revenue generator. Given time and a similar evolution, skill games might one day play a similar role in casinos.

More immediately, the prospect of online and mobile gambling offers a dilemma to casino operators: do they invest in and operate online gaming options,

\footnotetext{
${ }^{48}$ Las Vegas Visitor Profile 1998 (Las Vegas: Las Vegas Convention and Visitor Authority, 1999) and Las Vegas Visitor Profile 2017 (Las Vegas: Las Vegas Convention and Visitors Authority, 2018). For inflation data, see CPI INFLATION CALCULATOR, http://www.in2013dollars.com/1998-dollars-in-2017?amount=469.29.

${ }^{49}$ Elena Bolognini, Brittney Heisz, Dan Lin, Saajid Patel, and Olena Sapojnikova Redesigning Las Vegas: Attracting the Millennial Segment, American Marketing Association, (Feb. 2, 2019), accessed at: https://www.ama.org/resources/Pages/ redesigning-las-vegas-attracting-millennial-segment.aspx.

${ }^{50}$ Henry D. Fetter, No, Horse Racing Can't Be Saved - Even by a Triple Crown Winner, The AtLANTic, May 20, 2014, accessed at: https://www.theatlantic.com entertainment/archive/2014/05/no-horse-racing-cant-be-savedeven-by-a-triple-crownwinner/371255/.
}

\footnotetext{
${ }^{51}$ Reuters, Horse Racing Fading in Revenue, Popularity, Newsweek, May 8, 2016, accessed at: https://www.newsweek.com/horse-racing-fading-revenue-popularity457123, and Ryland Barton, As Interest in Horse Racing Declines, Track Turns to Other Options, NPR (May 5, 2017), accessed at: https://www.npr.org/2017/05/ 05/527013763/as-interest-in-horse-racing-declines-track-turns-to-other-options

${ }^{52}$ Chris Palmeri, Casinos Bet on Smoothie Slots, Desperate to Lure Millennials, BLOOMBerG (Jan. 26, 2018), accessed at: https://www.bloomberg.com/news/ articles/2018-01-26/casinos-bet-on-smoothie-slots-desperate-to-lure-millennials.

${ }^{53}$ Nicholas Huba, Skill-Based Games at Caesars Didn't Make the Cut, Press of AtLantic City (June 10, 2017), accessed at: https://www.pressofatlanticcity.com/ news/breaking/skill-based-games-at-caesars-didn-t-make-the-cut/article_770b7b830ed1-5681-b4a5-7e4a4c0aaed1.html.
} 
giving gamblers one less reason to visit their brickand-mortar casinos, which can represent billions of dollars of sunk capital? Or do they ignore online play, and run the risk of becoming Sears to online gaming's Amazon?

The experience of New Jersey, which accepted its first online bet in 2013, is instructive. Within five years of operation, its online industry can be said to be mature. New Jersey legalized online play in the face of an unprecedented collapse of its brickand-mortar gaming industry, which saw revenue fall by more than 50 percent due to the expansion of casino gaming to nearby states. ${ }^{54}$ Since 2015 , gaming revenues have begun to rebound, thanks in part to online play, which has grown steadily as a share of total gaming revenue. In 2014, the first full year of operation, online play accounted for less than five percent of total gaming revenues; in 2015 , the percentage increased to just under six percent; every subsequent year has seen increases, so that through November 2018, online play accounts for over 10 percent of all New Jersey gaming revenue, which is itself increasing (it is up more than three percent through November 2018). ${ }^{55}$

Thus, rather than cannibalizing brick-and-mortar revenue, online play is actually complementing it. The potential of online and mobile wagering is no more apparent than in the realm of sports betting, which New Jersey legalized in 2018. In November of that year, "Internet" betting (online and mobile) represented nearly 70 percent of all sports betting win for sportsbooks at casinos and North Jersey racetracks. ${ }^{56}$ While sports betting has provided a shot in the arm to New Jersey gaming revenues, the majority of bettors are doing so on their own, digital terms.

The advent of primarily digital customers would be a problem if casino resorts were single-purpose, like a department store. But casinos in Las Vegas have developed multiple revenue streams that have enabled them to grow, even as overall gaming revenues have

${ }^{54}$ Atlantic City Gaming Revenue (Center for Gaming Research, University of Nevada, Las Vegas, 2018), accessed at: https://gaming.unlv.edu/reports/ac_hist. pdf.

${ }^{55}$ Id. and Autumn Bassett, Atlantic City Casinos: September Summary (Las Vegas: Center for Gaming Research, University Libraries, University of Nevada Las Vegas, 2018), accessed at: https://gaming.unlv.edu/reports/2018_11_AC.pdf. failed to eclipse their pre-recession highs. Diversification has worked on the Strip, and it's beginning to be seen in traditionally gaming-centric markets as well. In 2017, for the first time, non-gaming revenues surpassed gaming revenues for Downtown Las Vegas, which was traditionally heavily dependent on gaming. ${ }^{57}$

At the same time, the split of gaming operators into property owners (via Real Estate Investment Trusts, or REITs) and operating companies might augur another future split. As gaming becomes a smaller part of what casinos offer and erstwhile casino-centric companies become either property owners or managers of diversified hospitality portfolios, it is possible that a major gaming operator might decide to spin off their gaming interests into a separate company that would then operate traditional casinos via a lease or revenue share agreement and online gaming via a branding partnership. Certainly, the competencies needed to successfully run the hospitality and resort development aspects of a gaming company and its gambling elements, which are increasingly online, are becoming progressively diverse.

It might not, then, be outrageous to see Caesars Entertainment, which has already spun off a REIT, VICI, further spin off Caesars Gaming, which would concentrate solely on brick-and-mortar and online/ mobile gaming. The hospitality operating company would then focus on providing a range of amenities for guests and developing new gaming and nongaming properties, while the gaming entity would be contracted to provide gaming services. Such a split would, necessarily, require the approval of regulators and may require some amendments to licensing requirements and procedures, but the quick adoption of the REIT model shows that it is not unprecedented.

Just because a variety of historical trends conspired to bring gambling and destination resorts together in the midcentury United States, does not mean

\footnotetext{
${ }^{56}$ New Jersey Sports Betting, November 2018 (Center for Gaming Research, University of Nevada, Las Vegas, 2018), accessed at: https://infograph.venngage. com/ps/ZujxToAh30k/new-jersey-sports-betting-november-2018.

${ }^{57}$ David G. Schwartz. Nevada Casinos: Departmental Revenues, 1984-2017 (Las Vegas: Center for Gaming Research, University Libraries, University of Nevada Las Vegas, 2018), accessed at: https://gaming.unlv.edu/reports/NV_departments_historic. pdf.
} 
that the twain will never part. Indeed, there are compelling reasons, borne out by the decreasing importance of gaming to resorts in the casino resort's birthplace, the Las Vegas Strip, that they may have an amicable breakup in the near future.

In the end, it should be remembered that people have been gambling for a long time, and in the absence of a fundamental shift in economics or culture, they will likely continue to do so. A final lesson from history is instructive: once, the game of faro was so popular that it was called "the game that won the West." Yet today, while more Americans gamble more money than they did during faro's nineteenth century heyday, faro is played only as a historical curiosity. The key for the gaming industry to survive ongoing shifts in player taste and demographics is to keep the fate of faro in mind. Games change, but gambling is eternal. To keep pace with gamblers (and relevant to the non-gambling leisure and business guests it increasingly caters to), the gaming industry must be nimble enough to offer customers games that they want in ways that they want, whether in person or digitally. And, it goes without saying, the corpus of law and regulation that guides the industry must evolve with these realities in mind. 